\title{
Black soldier fly larval meal in feed enhances growth performance, carcass yield and meat quality of finishing pigs
}

\author{
S.Y. Chia ${ }^{1,2}$, C.M. Tanga ${ }^{2}$, I.M. Osuga ${ }^{2,3}$, A.O. Alaru ${ }^{4}$, D.M. Mwangi ${ }^{4}$, M. Githinji ${ }^{4}$, T. Dubois ${ }^{2}$, S. Ekesi ${ }^{2}$, \\ J.J.A. van Loon ${ }^{1}$ and M. Dicke ${ }^{1 *}$ \\ ${ }^{1}$ Laboratory of Entomology, Wageningen University E Research, P.O. Box 16, 6700 AA Wageningen, the Netherlands; \\ ${ }^{2}$ International Centre of Insect Physiology and Ecology (ICIPE), P.O. Box 30772-00100, Nairobi, Kenya; ${ }^{3}$ Department \\ of Animal Sciences, Jomo Kenyatta University of Agriculture and Technology, P.O. Box 62000-00200, Nairobi, Kenya; \\ ${ }^{4}$ Non-Ruminant Research Institute (NRI), Kenya Agricultural and Livestock Research Organization (KALRO), \\ P.O. Box 169, Kakamega, Kenya; marcel.dicke@wur.nl
}

Received: 10 July 2020 / Accepted: 17 November 2020

(c) 2021 Wageningen Academic Publishers

OPEN ACCESS CC) (7) (2) RESEARCH ARTICLE

\begin{abstract}
Using black soldier fly (BSF, Hermetia illucens) larvae as a novel protein source substituting fishmeal (FM) in animal feeds is globally gaining momentum. BSF can be reared on agro-industrial residues. However, incorporating BSF larval meal (BSFLM) into finisher pig diets has received inadequate attention. This study evaluated the effects of replacing dietary FM with BSFLM on growth, carcass traits and meat quality of finisher pigs. A control diet (including FM: 0\% BSFLM) was compared with four dietary levels of replacement of FM with BSFLM at 25, 50, 75 or $100 \%$. Forty hybrid pigs (crossbreeds of purebred Large White and Landrace) were randomly allocated to the five different dietary treatments. Feed intake, body weight gain and feed conversion ratio were measured. After 98 days of feeding, all pigs were slaughtered for the evaluation of carcass and nutritional content of the organ and muscle tissues. Diet significantly affected pig growth performance. Carcass weight of pigs fed diets with BSFLM replacing FM by 50, 75 or 100\% (w/w) was higher than for pigs fed control diet with 100\% FM as protein source. Crude protein content of pork tissues was high (65-93\% on dry-matter basis) across all dietary groups. Therefore, BSFLM can replace FM in pig feed. This is relevant for commercial pig feed production and provides for the first time a nutritional analysis of pork derived from pigs raised on BSFLM.
\end{abstract}

Keywords: carcass quality, crude protein, finisher pig diet, insect larval meal, market weight

\section{Introduction}

Approximately one third of global meat production is derived from pigs (Bruinsma, 2003). In sub-Saharan Africa, pig production has great potential for raising household income of millions of resource-poor smallholder farmers especially women in the rural and peri-urban communities (Ouma et al., 2014). In Kenya, pig production is an important source of household income (Kagira et al., 2010; Mutua et al., 2010), especially for smallholder farmers who constitute 70\% of all producers (Githigia et al., 2012; Mbuthia et al., 2015). However, a major barrier for producers is the lack of high quality feed ingredients, especially major protein sources such as fishmeal (FM) and soybean meal. Reduced market availability of these protein sources throughout the year has led to an increase in feed costs, representing $60-70 \%$ of the total costs of pig production. Thus, cheaper, alternative sources of protein for inclusion in animal feed to substitute FM and soybean meal are urgently needed (Ardjosoediro and Neven, 2008; Fiaboe and Nakimbugwe, 2017).

Although FM has a good amino acid profile and mineral content, which can positively impact nutrition and meat quality of farmed animals (Cho and Kim, 2011), in Kenya it is mainly obtained from silver cyprinid fish Rastrineobola argentea $\mathrm{P}$, which constitutes the largest catch by weight of fish in Lake Victoria (Kolding et al., 2014). High demand 
for $R$. argentea has led to excessive fishing activities in Lake Victoria, prompting the lake regulatory authorities to institute periodic fishing bans. As a result, FM is not available in sufficient quantities throughout the year, leading to increased prices (Ardjosoediro and Neven, 2008). Therefore, novel protein sources, including edible insects, are needed to supplement the current sources of protein (Van Krimpen and Hendriks, 2019).

Insects contain high-quality proteins, fats and minerals, and are suitable alternatives to FM or soybean meal in animal feed (Makkar et al., 2014). The black soldier fly (BSF) Hermetia illucens L. (Diptera: Stratiomyidae) is widespread in the tropics and warm temperate regions of the world (Sheppard et al., 1994). BSF larvae (BSFL) feed on a variety of substrates including organic waste (Chia et al., 2018; Meneguz et al., 2018), converting residual nutrients into high-quality insect biomass (Barragan-Fonseca et al., 2017). Black soldier fly larval meal (BSFLM) has been used extensively in fish (Belghit et al., 2019; Xiao et al., 2018; Zarantoniello et al., 2018), poultry feeds (Onsongo et al., 2018) and to a lesser extent in weaners and grower pig feed (Biasato et al., 2019; Chia et al., 2019; Newton et al., 1977), but its use in finishing pig feed formulation has only been assessed occasionally (Yu et al., 2019).

A pig production cycle produces mature pigs either for slaughter or reproduction, and feed is the most critical input in every growth phase (i.e. piglet-grower-finisher) in commercial pig production. The finishing phase of pigs, a growth phase which typically precedes slaughter, is marked by considerable lean growth (Kim et al., 2005). Inclusion of BSFLM in pig feed thus far focused on the piglet stage and has not yet been extensively assessed on the finisher phase. Yu et al. (2019) replaced soybean meal with BSFLM in finisher pig feeds at the rate of 4 and $8 \%$, and investigated the colonic microbiota and bacterial metabolite production in the animals. They report that the inclusion of BSFL in pig feed may enhance mucosal immune homeostasis of finisher pigs through altering bacterial composition and metabolic profile in the colon mucosa.

Market weight is an important economic factor in pig production, impacting pork quality and profit. Furthermore, the values of different cuts of pig carcasses are different, and information on the proportion of primal cuts is important in assessing carcass yield to optimise profit (Kim et al., 2005). Body weight gain in finisher pigs and feed composition are important factors in pork production. About $80 \%$ of feed used in a farrow-finish operation is consumed in the grower-finisher phase (Njoku et al., 2015). Inadequate feed intake affects growth performance, thus impacting the cost of production.
Edible meat by-products including internal organs such as liver, lungs, heart, spleen and kidneys are generated through slaughter of pigs. These by-products make up an important portion of the animal's live weight and can provide essential nutrients to consumers who have less access to meat and meat products (Fayemi et al., 2018). However, their consumption is limited, partly because of perceived low nutritional quality, and varies among cultures and economic status (Seong et al., 2014). Information on the nutritional composition of edible pork by-products when fed insect-based feeds could positively influence consumer's acceptance of these by-products and ensure more widespread use of insect meal in pig feed formulation.

The present study evaluated the effect of replacing FM with BSFLM on growth performance, carcass yield and meat quality of finisher pigs until market weight, and assessed the nutritional composition of some major pork by-products including: heart, kidney, liver, longissimus dorsi (LM), lung and spleen tissues.

\section{Materials and methods}

\section{Study site}

The experiment was conducted at the Non-ruminant Research Institute (NRI) of the Kenya Agricultural and Livestock Research Organization (KALRO) located in Naivasha, Kenya.

\section{Insect meal and experimental diets}

BSFL were obtained from the Animal Rearing and Containment Unit (ARCU), International Centre of Insect Physiology and Ecology (icipe), Nairobi, Kenya. BSFL were reared on a mixture of brewers' spent grains from Kenya Breweries Limited (Nairobi, Kenya). BSFL were sterilised by washing in warm water $\left(84^{\circ} \mathrm{C}\right)$ for 10 minutes and then oven-dried using a stainless-steel drying machine model (CT-C-III Series hot air circulating drying oven, Henan Forchen Machinery Co., Zhengzhou, China). Dried BSFL were ground into BSFLM (Newton et al., 1977). The nutritional composition of the BSFLM used in the present study was previously reported by Chia et al. (2020). Diets were prepared to partially or completely replace FM and were formulated to be isonitrogenous and isoenergetic to meet requirements for finisher pigs (National Research Council, 1979). Nutritional composition of the most common fishmeal used in Kenya has been presented by Carter et al. (2015). FM content of a control (D0) diet was replaced at 25, 50, 75 and $100 \%$ with BSFLM to obtain D25, D50, D75 and D100, respectively, as experimental diets (Table 1). 
Table 1. Composition of experimental diets.

\begin{tabular}{|c|c|c|c|c|c|}
\hline \multirow[t]{2}{*}{ Parameter $^{1}$} & \multicolumn{5}{|c|}{ Diets $^{2}$} \\
\hline & DO & D25 & D50 & D75 & D100 \\
\hline \multicolumn{6}{|l|}{ Ingredient (kg) } \\
\hline Maize meal & 13.0 & 14.0 & 14.5 & 14.0 & 14.0 \\
\hline Wheat pollard & 46.5 & 35.0 & 34.0 & 32.3 & 36.0 \\
\hline Rice polishing & 27.5 & 33.8 & 33.0 & 34.0 & 30.0 \\
\hline Fishmeal & 7.0 & 5.2 & 3.5 & 1.8 & 0.0 \\
\hline BSFLM & 0.0 & 6.0 & 9.0 & 12.0 & 14.0 \\
\hline L-lysine & 1.0 & 1.0 & 1.0 & 1.0 & 1.0 \\
\hline DL-methionine & 1.0 & 1.0 & 1.0 & 1.0 & 1.0 \\
\hline Vitamin and mineral premix ${ }^{3}$ & 1.0 & 1.0 & 1.0 & 1.0 & 1.0 \\
\hline Bone meal & 1.3 & 1.3 & 1.3 & 1.3 & 1.3 \\
\hline Salt & 0.5 & 0.5 & 0.5 & 0.5 & 0.5 \\
\hline Limestone & 1.2 & 1.2 & 1.2 & 1.2 & 1.2 \\
\hline \multicolumn{6}{|l|}{ Calculated nutrients } \\
\hline Crude protein (\%DM) & 16.2 & 16.4 & 16.4 & 16.5 & 16.4 \\
\hline Energy (MJ/kg DM) & 11.6 & 11.7 & 11.7 & 11.7 & 11.8 \\
\hline Crude fat (\% DM) & 6.8 & 9.3 & 10.2 & 11.3 & 11.5 \\
\hline Crude fibre (\% DM) & 2.7 & 3.0 & 3.2 & 3.4 & 3.6 \\
\hline \multicolumn{6}{|l|}{ Analysed nutrients } \\
\hline Dry matter (DM) (\%) & 92.6 & 93.1 & 93.6 & 92.2 & 94.1 \\
\hline Crude protein (\% DM) & 12.9 & 14.9 & 15.3 & 14.8 & 16.3 \\
\hline \multicolumn{6}{|l|}{ Essential amino acids (\% DM) } \\
\hline Lysine & 1.1 & 1.2 & 1.3 & 1.2 & 1.3 \\
\hline Methionine & 0.6 & 0.7 & 0.7 & 0.5 & 0.5 \\
\hline Methionine + cystine & 0.9 & 0.9 & 0.9 & 0.7 & 0.8 \\
\hline Isoleucine & 0.4 & 0.4 & 0.5 & 0.4 & 0.5 \\
\hline Leucine & 0.8 & 0.9 & 0.9 & 0.9 & 1.0 \\
\hline Threonine & 0.4 & 0.5 & 0.5 & 0.4 & 0.5 \\
\hline Phenylalanine & 0.5 & 0.6 & 0.6 & 0.5 & 0.6 \\
\hline Valine & 0.6 & 0.6 & 0.7 & 0.6 & 0.8 \\
\hline Arginine & 0.8 & 0.8 & 0.8 & 0.7 & 0.9 \\
\hline Histidine & 0.3 & 0.3 & 0.3 & 0.3 & 0.4 \\
\hline \multicolumn{6}{|l|}{ Nonessential amino acids (\% DM) } \\
\hline Alanine & 0.7 & 0.8 & 0.8 & 0.8 & 0.9 \\
\hline Aspartic acid & 0.9 & 1.0 & 1.1 & 1.0 & 1.2 \\
\hline Cystine & 0.2 & 0.2 & 0.2 & 0.2 & 0.2 \\
\hline Glutamic acid & 1.9 & 2.0 & 2.0 & 1.8 & 2.1 \\
\hline Glycine & 0.7 & 0.7 & 0.8 & 0.7 & 0.8 \\
\hline Proline & 0.7 & 0.8 & 0.8 & 0.8 & 0.9 \\
\hline Serine & 0.5 & 0.6 & 0.6 & 0.5 & 0.6 \\
\hline \multicolumn{6}{|c|}{ 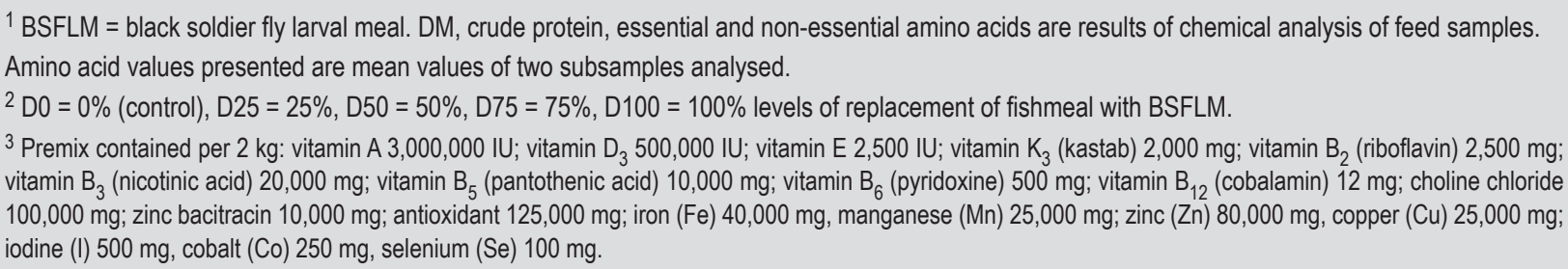 } \\
\hline
\end{tabular}




\section{Proximate, amino acid and mineral composition of experimental diets}

The dry matter content of formulated feed samples was gravimetrically determined after loss of water. The samples were heated to $103 \pm 2{ }^{\circ} \mathrm{C}$ for 3 hours until constant sample weight for two consecutive readings. Ash content was determined by ignition of samples at $550{ }^{\circ} \mathrm{C}$ in a muffle furnace. Dried, ground samples were exposed to an electromagnetic scan in the absorbance mode using near infrared spectroscopy at Cropnuts (Nairobi, Kenya). The crude protein, fat, starch, oil, acid detergent fibre, neutral detergent fibre, sugar and digestibility values were determined following standard laboratory procedures (Núñez-Sánchez et al., 2012; Rosales et al., 2011). The amino acid composition of experimental diets was analysed by AMINOLab (Evonik Industries, Hanau, Germany) using an amino acid analyser (Biochrom 30 plus, Biochrom Ltd. Cambridge, UK) (AOAC, 1995; Llames and Fontaine, 1994).

Mineral composition of feed samples was analysed by inductively coupled plasma-optical emission spectrometry (ICP-OES) at Cropnuts (Table 2). Ground feed samples were microwave-digested using a mixture of nitric acid and hydrochloric acid, and the resulting digest was used for ICPOES analysis to determine the following minerals: boron, molybdenum, iron $(\mathrm{Fe})$, copper $(\mathrm{Cu})$, zinc $(\mathrm{Zn})$, cobalt, manganese $(\mathrm{Mn})$, sodium $(\mathrm{Na})$, sulphur $(\mathrm{S})$, magnesium $(\mathrm{Mg})$, potassium $(\mathrm{K})$, phosphorus $(\mathrm{P})$ and calcium $(\mathrm{Ca})$ (Dos Santos et al., 2012; Sreenivasulu et al., 2017).

\section{Animals and housing}

Hybrid grower pigs (crossbreeds of purebred Large White and Landrace) comprising of 20 boars and 20 gilts, with mean body weight of $54.3 \pm 0.93 \mathrm{~kg}$, were randomly assigned to the five dietary treatments, with eight replicate pigs (four boars and four gilts) per treatment. Pigs were placed individually in pens $(3.7 \times 1.9 \mathrm{~m})$ with concrete floors. Each pen was provided with a one-sided feeding trough $(1.8 \times 0.2 \times 0.2 \mathrm{~m})$ and a nipple drinker. Each pen was labelled with a number and diet type while each animal was identified with a unique number by ear tattooing. Pig pens were cleaned every day by scrubbing the floor using straight brooms and water. Pigs were allowed ad libitum access to feed and water throughout the experiment.

Table 2. Mineral and proximate composition (dry matter basis) of experimental diets. ${ }^{1}$

\begin{tabular}{|c|c|c|c|c|c|}
\hline \multirow[t]{2}{*}{ Parameter } & \multicolumn{5}{|l|}{ Diets $^{2}$} \\
\hline & DO & D25 & D50 & D75 & D100 \\
\hline Boron (mg/kg) & 2.6 & 3.7 & 2.6 & 2.6 & 1.68 \\
\hline Molybdenum (mg/kg) & 1.1 & 1.0 & 0.8 & 0.8 & 10.5 \\
\hline Iron $(\mathrm{mg} / \mathrm{kg})$ & 374.2 & 522.9 & 404.4 & 433.1 & 499 \\
\hline Copper (mg/kg) & 13.2 & 11.6 & 13.7 & 10.7 & 24.4 \\
\hline Zinc (mg/kg) & 66.3 & 92.6 & 82.4 & 74.8 & 123 \\
\hline Cobalt (mg/kg) & 0.1 & 0.2 & 0.2 & 0.1 & 0.44 \\
\hline Manganese (mg/kg) & 159.7 & 232.5 & 203.3 & 200.2 & 209 \\
\hline Sodium (mg/kg) & $2,833.7$ & $3,744.5$ & $3,049.2$ & $3,384.1$ & 942 \\
\hline Sulphur (\%) & 0.4 & 0.4 & 0.3 & 0.3 & 0.3 \\
\hline Magnesium (\%) & 0.5 & 0.6 & 0.5 & 0.5 & 0.58 \\
\hline Potassium (\%) & 0.8 & 1.1 & 0.9 & 0.9 & 0.93 \\
\hline Phosphorus (\%) & 0.8 & 1.0 & 1.0 & 0.9 & 0.64 \\
\hline Calcium (\%) & 2.5 & 3.0 & 2.6 & 2.1 & 1.58 \\
\hline Sugar (\%) & 2.5 & 3.6 & 6.2 & 5.6 & 8.66 \\
\hline Starch $(\%)$ & 32.3 & 17.1 & 25.5 & 25.4 & 29.8 \\
\hline Ash (\%) & 8.5 & 12.3 & 8.3 & 9.3 & 9.53 \\
\hline Acid detergent fibre (\%) & 16.8 & 25.7 & 19.8 & 20.7 & 18.1 \\
\hline Neutral detergent fibre (\%) & 39.1 & 50.1 & 41.1 & 42.3 & 40.2 \\
\hline Digestibility (\%) & 77.8 & 67.9 & 75.4 & 75.0 & 72.9 \\
\hline Oil (\%) & 4.7 & 6.5 & 8.6 & 8.6 & 11.3 \\
\hline Energy (MJ/kg) & 9.3 & 7.6 & 10.2 & 10.0 & 13.4 \\
\hline
\end{tabular}




\section{Growth performance}

Initial body weight of the pigs was recorded at the start of the experiment and subsequently the pigs were weighed on a weekly basis using a suspended weighing scale (model 235, Salter, Bilston, England). The experiment lasted 14 weeks and the weekly body weight values were used to calculate average daily weight gain (ADG). Feed offered to the pigs and the unconsumed portions were weighed daily using a digital platform weighing scale (XK3190-A12, Gromy Scale Co., Hangzhou, China) to calculate average daily feed intake (ADFI). Feed conversion ratio (FCR) was calculated as total feed consumed divided by the body weight gain at the end of the experiment.

\section{Slaughter and carcass characteristics}

At the end of the experiment (after 14 weeks), all 40 pigs, consisting of eight ( 4 boars and 4 gilts) pigs per dietary treatment were slaughtered and analysed for carcass yield; cut-up parts (parts to which a pig is cut, other than the primal cuts and include: head, collar butt, tenderloin, rump, trotters and tail); organ weight; and composition of muscle, bone, fat and skin in primal cuts (large parts in which the pig is first cut: shoulder, ham, loin and belly) at the end of the experiment. All pigs were slaughtered at the slaughter facility of the Non-ruminant Research Institute of the Agricultural and Livestock Research Organization, Naivasha, Kenya where the feeding trial on pigs was conducted. Pigs were weighed and fasted for about 18 hours after which the fasted weight of each pig was recorded before it was stunned.

Pigs were carefully slaughtered following prescriptions according to the Kenya Society for the Protection and Care of Animals, Naivasha, Kenya. Pigs were immobilised by head stunning, using a stunning gun and bled by incision, cutting through the jugular vein between the skull and the atlas after which complete dehairing was done. Following dehairing, the stomach of each pig was opened along the greater curvature and eviscerated. After evisceration, the remaining part was weighed within 45 minutes postmortem to determine the hot carcass weight ( $\mathrm{HCW})$ and later expressed as percentage of the ending live weight to obtain the dressing percentage (DP). The head was removed by cutting through the occipito-atlas joint. The trotters were removed by sawing through the hock joint at a right angle to the long axis of the leg. The carcass was split longitudinally by sawing along the dorsal midline and the right half of each carcass was dissected into main cuts (ham, shoulder, loin and belly) and into other parts (collar butt, tenderloin and rump). The ham was separated by locating the division between the second and third sacral vertebrae and then sawing perpendicularly to the long axis of the carcass. The shoulder was separated from the loin and belly by a straight cut between the second and third ribs.
The shoulder cut was further separated into the shoulder picnic (portion closest to the knee) and collar butt (portion closest to the spine of the pig). The middle portion of the carcass side was divided into the loin and belly by a straight cut from the edge of the tenderloin muscle on the ham end through the front rib tight against the protruding edge of the split backbone. The rump is the portion posterior to the loin and anterior to the tail and was separated by cutting just below the exposed pelvic or aitchbone (Njoku et al., 2015; Sheridan et al., 1991). For each cut, the weight was recorded using a digital weighing scale. The four main cuts (ham, shoulder picnic, loin and belly) were deboned and the skin plus subcutaneous fat removed. The weight of the dissected lean (muscle), bone, skin plus fat of each of the main cuts was recorded and expressed as a percentage of the weight of the cut.

The unskinned loin portion of the half carcass was sectioned between the $10^{\text {th }}$ and $11^{\text {th }}$ rib and after exposing the loin eye of the LM, the surface of the loin eye was covered with a transparent plastic grid $(20 \times 15 \mathrm{~cm})$ marked out into squares of one centimetre $\left(\mathrm{cm}^{2}\right)$ and the number of squares covered by the grid counted to obtain the loin eye area (LEA). The $10^{\text {th }}$ rib back fat depth (TRFD) was measured at three quarters of the distance of the lumber muscle from the dorsal process of the vertebral column (Lowell et al., 2018), using a digital venier caliper (VonHaus 6" $150 \mathrm{~mm}$ Digital Caliper Micrometer Vernier Gauge Tool, VonHaus, Manchester, UK). The fat-free index (FFI) was estimated using the following equation, described in procedure 1 for ribbed carcasses (Burson, 2006) and used by Lowell et al. (2018).

$\underline{\text { FFI }=8.588+\left((0.465 \times \mathrm{HCW}, \mathrm{lb})-(21.896 \times \mathrm{TRFD}, \mathrm{in})+\left(3.005 \times \mathrm{LEA}^{\mathrm{in}}{ }^{2}\right)\right) \times 100}$ HCW

Where FFI = fat free index, HCW = hot carcass weight, TRFD $=10^{\text {th }}$ rib fat depth, LEA $=$ loin eye area.

\section{Proximate and mineral composition of pork tissues}

The heart, kidney, liver, LM, lung and spleen tissues from slaughtered pigs were freeze-dried using a Benchtop Freeze Dryer (VirTis AdVantage 2.0, SP Scientific, Gardiner, NY, USA). Dried tissue samples were crushed into powder using a blender (Preethi Trio Mixer Grinder 500W, Chennai, India). Samples were analysed following the procedures described by the Association of Analytical Chemists (AOAC, 1990). Nitrogen content (\%) was determined using the Kjeldahl method. The crude protein (CP) was then determined by multiplying the nitrogen content by the factor 6.25 . Fat content was determined using the Velp solvent extractor (SER 148/6, VELP Scientifica, Usmate, Italy) with ethyl ether as extractant. Ash content was determined by heating at $550{ }^{\circ} \mathrm{C}$ overnight. The organic matter (OM) was then determined by subtracting ash content from 100 . 
Pork tissues were microwave-digested using a mixture of $65 \%$ nitric acid, $37 \%$ hydrochloric acid and 30\% hydrogen peroxide (Sigma-Aldrich, St. Louis, MO, USA) (Mohammed et al., 2017). Minerals including $\mathrm{Ca}, \mathrm{Cu}, \mathrm{Fe}, \mathrm{K}, \mathrm{Mg}, \mathrm{Mn}, \mathrm{Na}$, $\mathrm{P}, \mathrm{S}$, and $\mathrm{Zn}$ in the digested samples were determined by inductively coupled plasma atomic emission spectrometry (ICP-AES).

\section{Statistical analysis}

Statistical analyses of the data were performed with $\mathrm{R}$ software (version 3.5.1; https://www.r-project.org/) by using a general linear model, which included: diet, sex and their interaction as independent variables for the analysis of ADG, ADFI, FCR, body weight gain and final body weight (FBW), fasted body weight, carcass weight, DP, LEA and FFI. For the cut up parts, visceral organs and composition of the primal cut, diet was included in the model as the independent variable. The model for each analysis included all independent variables which were removed one by one until the Akaike Information Criterion was at a minimal level. Mean effects were considered statistically significant at $P<0.05$, with least significant difference test (LSD) as post-hoc test.

\section{Ethical approval}

Ethical approval for the study was provided by the Institutional Animal Care and Use Committee of KALRO Veterinary Science Research Institute; approval code no. KALRO-VSRI/ IACUC019/30082019.

\section{Results}

\section{Growth performance}

Initial body weight of the pigs at the start of the experiment was similar for all five treatments (Table 3). All pigs showed healthy growth throughout the experimental period. Diet significantly affected ADG (Figure 1A). At D50, D75 and D100, ADG was higher than for D0 (Figure 1A). Sex did not affect ADG $(P=0.30)$. FBW differed significantly among diets (Figure 1B). At D50 and D100, FBW was significantly higher than at D0 and D25. FBW differed significantly between boars and gilts $(P=0.014)$. Boars and gilts had a mean FBW of $119.6 \pm 0.13 \mathrm{~kg}$ and $104.3 \pm 3.42 \mathrm{~kg}$ respectively, but the interaction of diet and sex on FBW was not significant $(P=0.13)$. Neither diet nor sex affected ADFI and the interaction between diet and sex for ADFI was not significant (Table 3). Diet significantly affected FCR (Figure 2). At D50, D75 and D100, FCR was significantly lower $(P<0.001)$ than at D0 and D25. Sex did not affect FCR $(P=0.07)$ and there was no interaction effect of diet and sex on FCR $(P=0.72)$.

\section{Carcass yield}

Fasted weight and carcass weight differed significantly among diets (Table 3). Fasted weight and carcass weight were higher at D50, D75 and D100 than at D0 and D25. Sex significantly affected fasted weight and carcass weight (Table 3). There were significant interactions between the effect of diet and sex on fasted weight and carcass weight (Table 3). For boars, fasted weight at D100 was significantly higher than at D0, D75. For gilts, fasted weight at D100 did not differ significantly from that at D50 and D75, but differed significantly from D0 and D25 (Table 3). DP did not differ among dietary treatments (Table 3). Sex did not affect DP, but there was an interaction effect of diet and sex on DP (Table 3). LEA did not differ among diets. Sex did not affect LEA, and there was no interaction effect of diet and sex on LEA (Table 3). Back fat depth measured at the $10^{\text {th }}$ rib increased with increased replacement of FM with BSFLM (Supplementary Figure S1). Overall, back fat depth at D100 differed significantly $(P=0.004)$ from that obtained at D0, D25 and D50 (Supplementary Figure S1). FFI was significantly lower for boars and gilts at D100 than at D0 (Table 3).

\section{Cut-up parts and organ weight}

The weight of primal cuts (belly, ham and loin) differed significantly among diets (Figure 3). At higher rates of replacement of FM by BSFLM, primal cuts (belly, ham and loin) weighed significantly more than for pigs fed lower levels of replacement (Figure 3). The head weight, tenderloin weight, rump weight and tail weight differed significantly among dietary treatments (Table 4). Spleen and testes weighed significantly more when pigs were fed higher levels of BSFLM than those fed lower levels of BSFLM, whereas heart, liver, kidneys, lungs and ovaries weights did not differ significantly across dietary treatments (Table 4). Diet significantly affected the amount of fat-skin (FS) in primal cuts (Supplementary Figure S2). At D100, FS was higher compared to D0, except in the shoulder cut for which values were not statistically different (Supplementary Figure S2). The ham had the lowest FS (Supplementary Figure S2). In ham, shoulder, loin and belly, the weight of muscle and bone tissues was not statistically different among diets, except at D100 where bones from the loin weighed less compared to the rest of the dietary treatments (Supplementary Table S1).

\section{Proximate and mineral composition of pork tissues}

Crude protein content of pork tissues differed significantly among diets (Figure 4). At D50, overall CP content was significantly higher compared to other dietary treatments investigated. Tissue type significantly affected CP $(P<0.001)$. The interaction effect of diet and tissue type on $\mathrm{CP}$ content was significant $(P<0.0001)$. The average $C P$ content ranged 


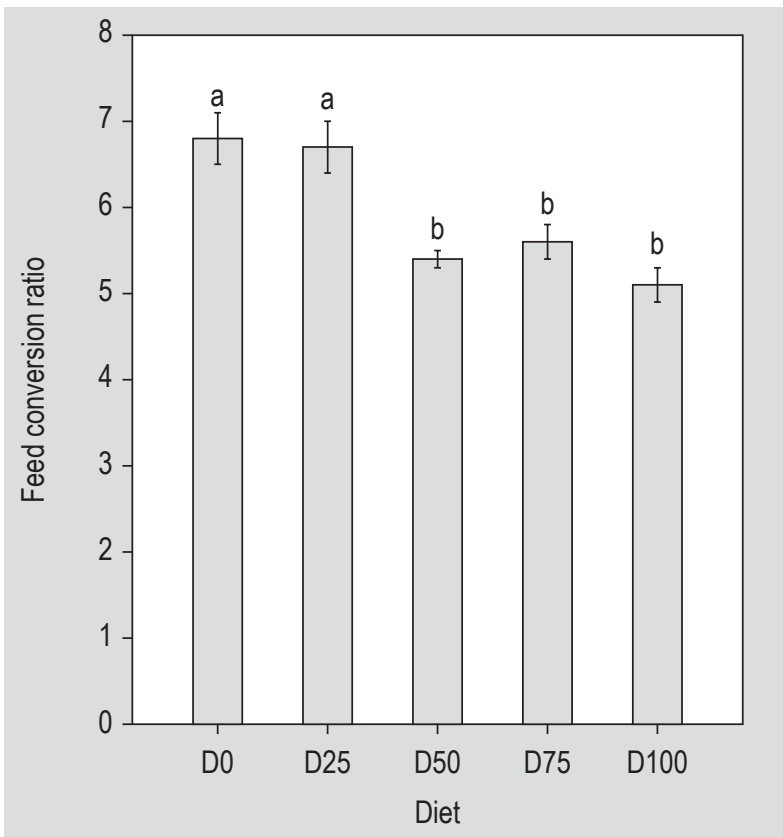

Figure 2. Mean ( \pm SE) feed conversion ratio (FCR) for finisher pigs fed black soldier fly larval meal-based diets and a control diet. Means followed by different letters are significantly different (GLM, $P<0.05$; least significant difference test). $D 0=$ $0 \%$ (control), D25 $=25 \%, \mathrm{D} 50=50 \%, \mathrm{D} 75=75 \%, \mathrm{D} 100=100 \%$ levels of replacement of fishmeal with black soldier fly larval meal. For each diet, $n=8$.

between 65\% (heart tissue) and 93\% (lung tissue) (Figure 4). The heart and LM tissues from pigs fed insect-based diets (D25, D50, D75 and D100) had higher crude fat contents than those fed the control diet (D0) (Figure 4). OM content differed significantly among diets (Figure 4). Overall, tissue samples at D100 had higher OM content than the other diets investigated. Tissue type significantly affected $\mathrm{OM}$ $(P<0.001)$.

Water content was only slightly affected by diet type. Overall, diet type had no significant effect $(P=0.554)$ on water content of tissues, whereas there was a significant effect $(P<0.0001)$ of tissue type on water content. Liver and LM tissues from pigs fed D25, D50, D75 and D100 had significantly higher $(P<0.0001$ and $P=0.012$, respectively) water contents than samples from pigs fed D0, whereas the water content of heart, kidney, lung and spleen tissue samples were not influenced by diet type $(P=0.141, P=0.592$, $P=0.462$ and $P=0.289$, respectively) (Figure 4). There was no significant interaction between diet and tissue type on water content $(P=0.167)$.

Potassium, P, S and Na were the major macro-minerals detected in all tissues across all diets. In heart, lung, LM and spleen tissues, $\mathrm{K}$ was the most abundant macro-mineral followed by $\mathrm{P}$ and $\mathrm{S}$. Levels of $\mathrm{K}$ and $\mathrm{P}$ were not significantly different in kidney tissues, while in liver tissues, $\mathrm{P}$ was the most abundant mineral (Figure 5A). Spleen, liver and LM tissues from pigs fed BSFLM-based diets had higher concentrations of $\mathrm{K}$ than those from pigs fed the control diet (D0), except in the heart where D25 and D100 had lower $\mathrm{K}$ contents (Figure 5A). In all tissues, Ca had the lowest concentrations among the macro-minerals detected. Among micro-minerals, Fe was most abundant in all tissues, except LM in which $\mathrm{Zn}$ had the highest concentration. Overall, Fe and $\mathrm{Zn}$ were the most abundant micro-minerals followed by $\mathrm{Cu}$ (Figure 5B). The LM tissue from pigs fed

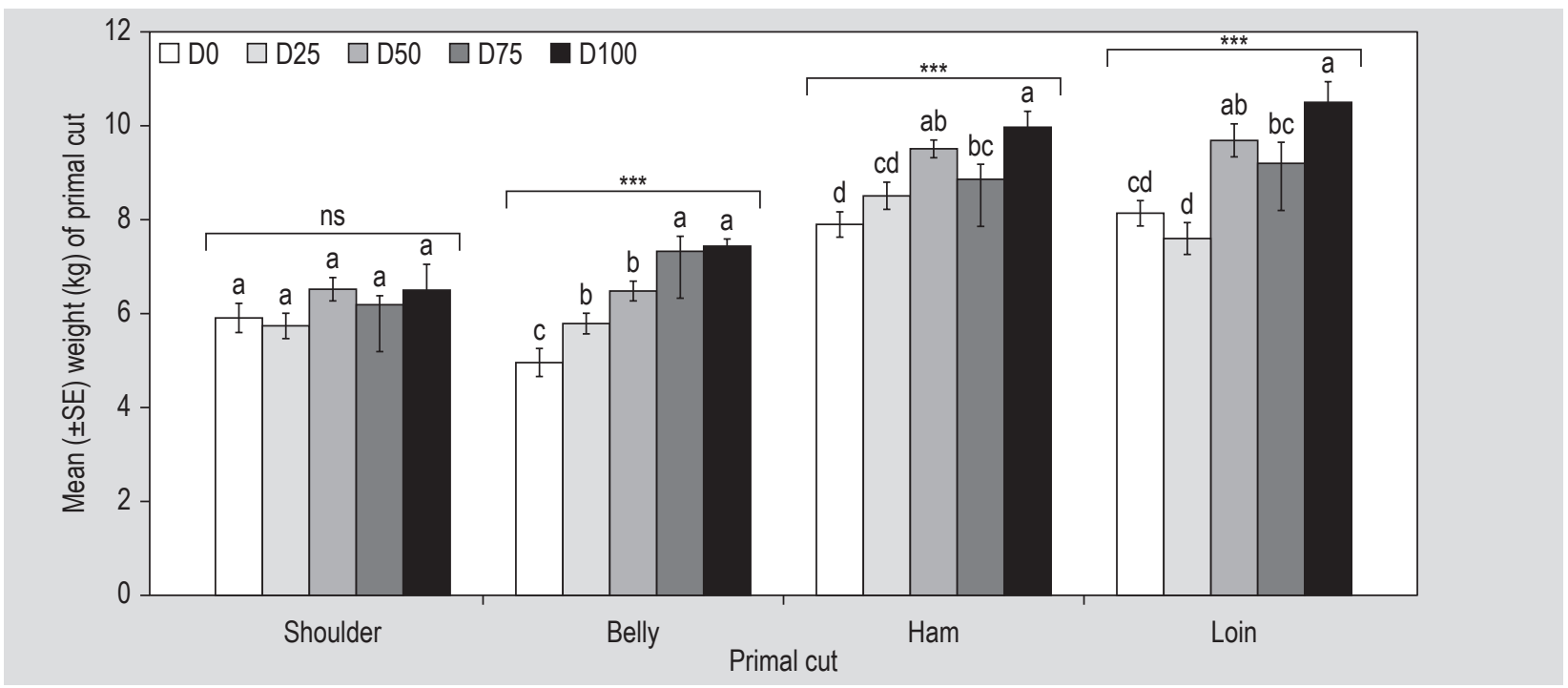

Figure 3. Mean weight $( \pm \mathrm{SE})$ of primal cuts of half carcass in finisher pigs fed black soldier fly larval meal-based diets and a control diet. Means within each primal cut followed by different letters are significantly different (GLM, $P<0.05$; least significant difference test). DO $=0 \%$ (control), D25 $=25 \%$, D $50=50 \%, D 75=75 \%, D 100=100 \%$ levels of replacement of fishmeal with black soldier fly larval meal. ${ }^{* *}$ : $P<0.001$, ns: not significant. For each diet, $n=8$. 
Table 4. Effect of dietary inclusion of black soldier fly larval meal (BSFLM) on cut-up parts of carcasses and visceral organs in slaughtered pigs. ${ }^{1,2}$

\begin{tabular}{|c|c|c|c|c|c|c|}
\hline \multirow[b]{2}{*}{ Parameter } & \multicolumn{5}{|l|}{ Diets } & \multirow[b]{2}{*}{$P$-value, GLM } \\
\hline & DO & D25 & D50 & D75 & D100 & \\
\hline \multicolumn{7}{|l|}{ Cut-up parts (kg) } \\
\hline Head weight & $6.27 \pm 0.13^{b}$ & $6.25 \pm 0.25^{b}$ & $7.26 \pm 0.22^{\mathrm{a}}$ & $7.07 \pm 0.22^{a}$ & $6.89 \pm 0.35^{\mathrm{ab}}$ & 0.014 \\
\hline Collar butt weight & $3.86 \pm 0.13$ & $3.88 \pm 0.14$ & $4.15 \pm 0.19$ & $3.99 \pm 0.24$ & $3.70 \pm 0.31$ & 0.67 \\
\hline Tenderloin weight & $0.61 \pm 0.05^{c}$ & $0.69 \pm 0.05^{b c}$ & $0.78 \pm 0.04^{\mathrm{ab}}$ & $0.82 \pm 0.04^{a}$ & $0.81 \pm 0.02^{\mathrm{a}}$ & 0.003 \\
\hline Rump weight & $2.34 \pm 0.16^{d}$ & $2.69 \pm 0.0 \mathrm{gcd}^{\mathrm{cd}}$ & $3.34 \pm 0.15^{\mathrm{ab}}$ & $2.94 \pm 0.15^{b c}$ & $3.60 \pm 0.29 a$ & $<0.001$ \\
\hline Trotters weight & $1.67 \pm 0.05$ & $1.70 \pm 0.07$ & $1.90 \pm 0.07$ & $1.85 \pm 0.07$ & $1.90 \pm 0.10$ & 0.08 \\
\hline Tail weight & $0.18 \pm 0.01^{\mathrm{C}}$ & $0.18 \pm 0.02^{c}$ & $0.25 \pm 0.01^{b}$ & $0.28 \pm 0.02^{\mathrm{ab}}$ & $0.30 \pm 0.02^{\mathrm{a}}$ & $<0.001$ \\
\hline \multicolumn{7}{|l|}{ Organ weight $(\mathrm{kg})$} \\
\hline Heart weight & $0.37 \pm 0.02$ & $0.40 \pm 0.03$ & $0.46 \pm 0.04$ & $0.44 \pm 0.02$ & $0.43 \pm 0.03$ & 0.09 \\
\hline Liver weight & $1.62 \pm 0.07$ & $1.47 \pm 0.07$ & $1.63 \pm 0.06$ & $1.50 \pm 0.04$ & $1.67 \pm 0.06$ & 0.12 \\
\hline Kidneys weight & $0.33 \pm 0.02$ & $0.29 \pm 0.02$ & $0.34 \pm 0.02$ & $0.29 \pm 0.02$ & $0.32 \pm 0.02$ & 0.17 \\
\hline Lungs weight & $0.74 \pm 0.06$ & $0.64 \pm 0.04$ & $0.67 \pm 0.04$ & $0.67 \pm 0.04$ & $0.72 \pm 0.07$ & 0.69 \\
\hline Spleen weight & $0.13 \pm 0.01^{c}$ & $0.13 \pm 0.01^{c}$ & $0.17 \pm 0.01^{a}$ & $0.16 \pm 0.01^{\mathrm{ab}}$ & $0.17 \pm 0.01^{a}$ & 0.017 \\
\hline Testes weight & $0.82 \pm 0.08^{c}$ & $1.03 \pm 0.05^{b}$ & $1.12 \pm 0.03^{\mathrm{ab}}$ & $1.24 \pm 0.08^{\mathrm{a}}$ & $1.31 \pm 0.06^{\mathrm{a}}$ & $<0.001$ \\
\hline Ovaries weight & $0.02 \pm 0.004$ & $0.02 \pm 0.007$ & $0.02 \pm 0.005$ & $0.02 \pm 0.002$ & $0.02 \pm 0.001$ & 0.59 \\
\hline
\end{tabular}

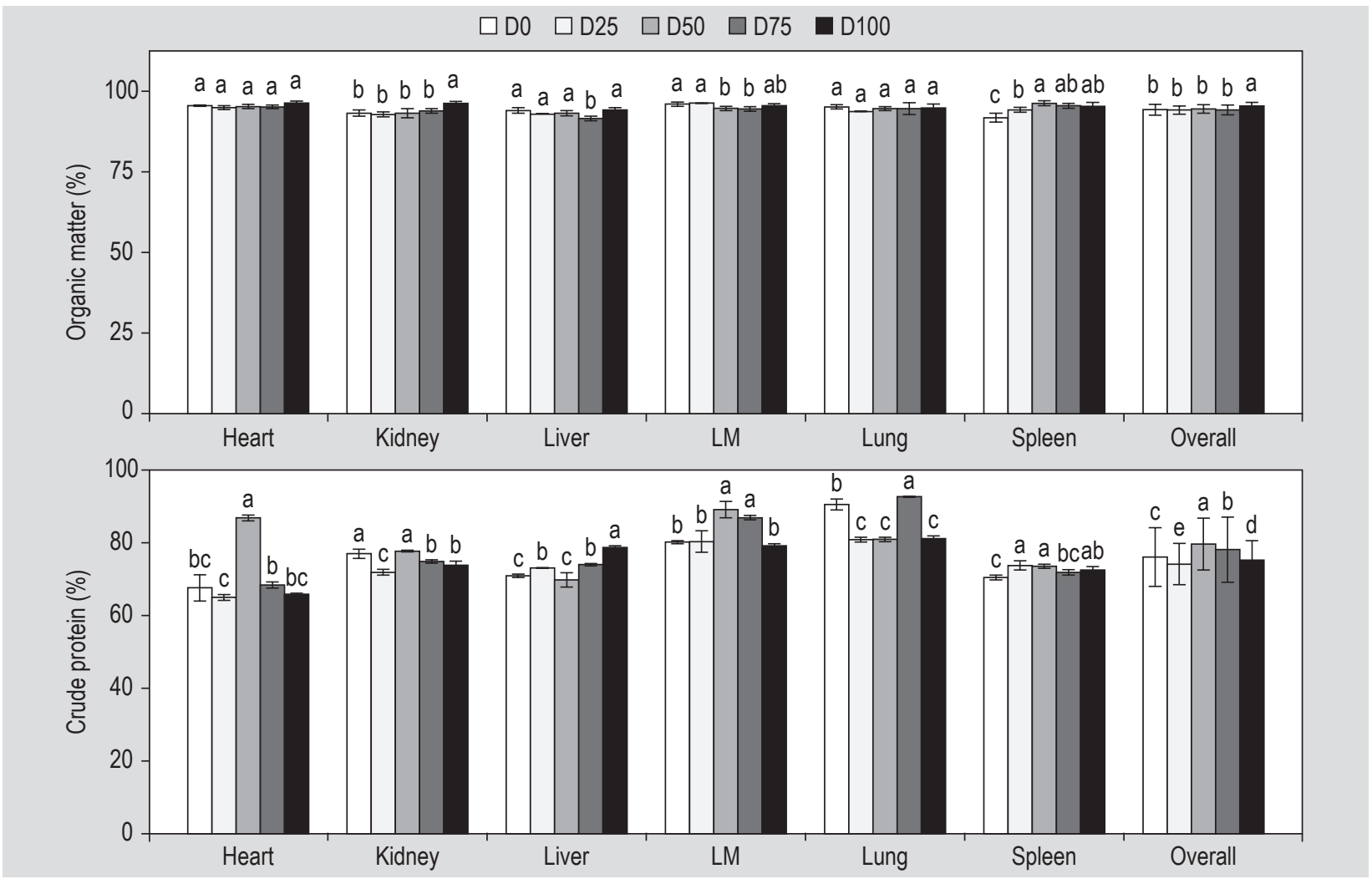

Figure 4. Proximate composition (\% dry matter basis) (mean \pm SD) of organ and muscle tissues of finisher pigs. D0 $=0 \%$ (control), $D 25=25 \%, D 50=50 \%, D 75=75 \%, D 100=100 \%$ levels of replacement of fishmeal with black soldier fly larval meal. LM = longissimus dorsi (loin muscle). Bars followed by different letters are significantly different (GLM, $P<0.05$; least significant difference test). Bars for crude fat represent mean value of two subsamples analysed. No statistical analysis was performed on the crude fat data. 


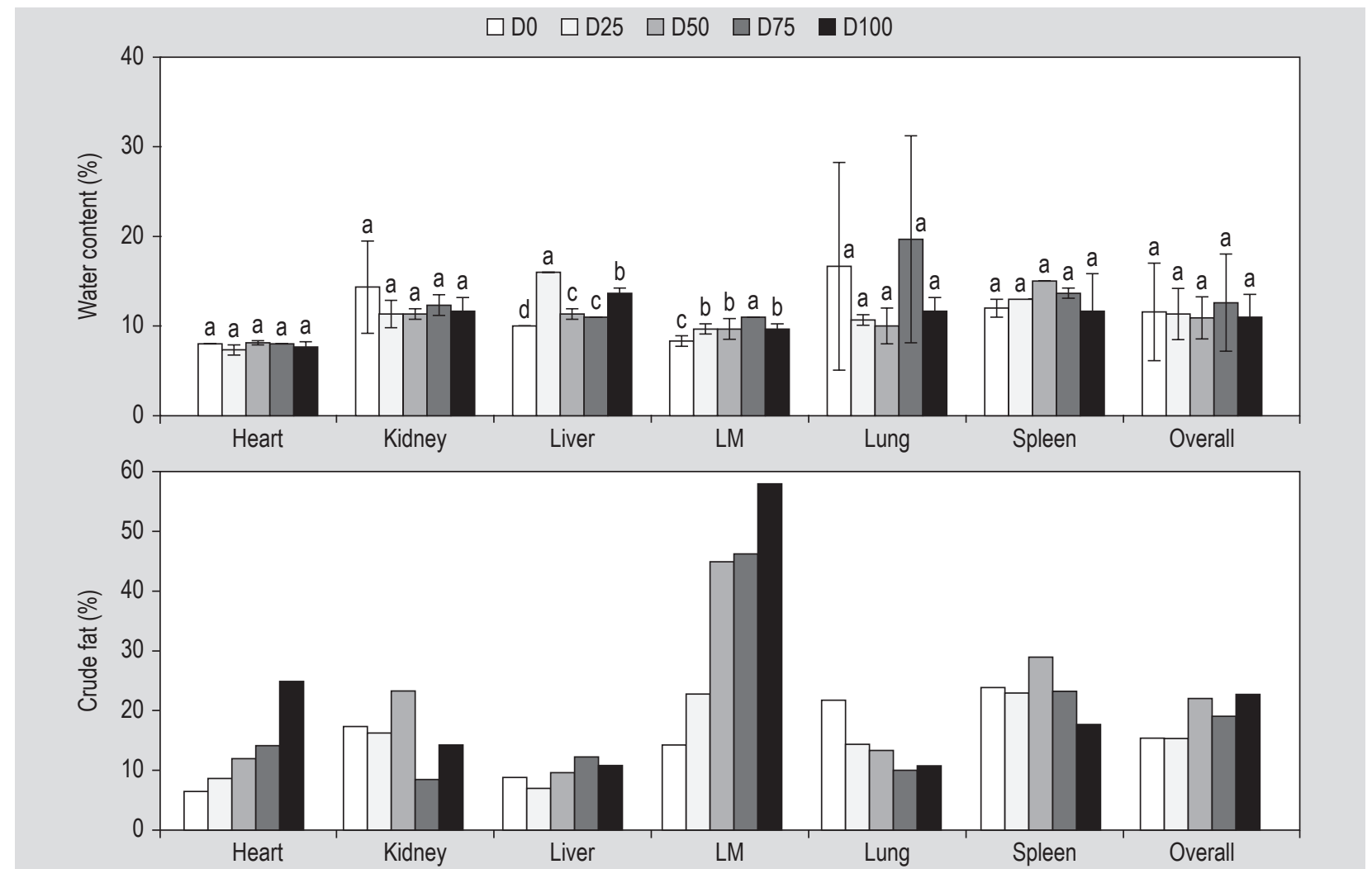

Figure 4. Continued.

D100 contained higher concentrations of Fe and $\mathrm{Zn}$ than those fed D0 (Figure 5B).

\section{Discussion}

BSFL are an alternative source of animal protein and have been used in aquaculture, poultry and piglet feeds to replace either FM or soybean meal (Makkar et al., 2014). The present study used partial or complete dietary replacement of FM by BSFLM to demonstrate for the first time the value of BSFLM on growth performance, carcass traits and nutritional value of finisher pigs. Identifying BSFLM as a feed ingredient that guarantees high-quality pork products will not only help to limit dependence on the traditional feed protein sources but will also provide an alternative protein source for farmers in times of scarcity.

Most importantly, our results revealed important positive effects of the insect-based diets on growth performance, feed conversion and carcass traits of finisher pigs. Our study showed that higher levels (50-100\%) of replacement of FM with BSFLM, resulted in higher body weight, higher feed conversion and higher carcass yield than the FM-based control diet (D0). Pork by-products had high (65-93\%) CP levels. A shortcoming in the present study is the difference in $\mathrm{CP}$ content between calculated and analysed values. This discrepancy can be attributed to accidental or deliberate adulteration of fishmeal with inorganic material such as shells of Pila ovata and sand to increase weight along the value chain (Nalwanga et al., 2009). The CP content of fish has been observed to decrease from primary source (landing sites) to retail outlets (Nalwanga et al., 2009). Given that the entire feed for the current study was formulated once, we couldn't change the dynamics. We therefore recommend that future studies should be more careful with the introduction of fishmeal in formulated products. The proportion of fat in the primal cuts was affected by diet while the muscle and bone tissues were not, except in the loin.

Previous studies had shown that inclusion of dried BSFLM in replacement of soybean meal, FM or dried plasma, either did not affect or positively influenced piglet growth performance parameters (Biasato et al., 2019; Newton et al., 1977; Spranghers et al., 2018). Moreover, replacing soybean meal by BSFLM in finisher pig feed results in beneficial changes in the microbiota and metabolites of the colonic digesta and mucosal immune gene expression in finisher pigs (Yu et al., 2019). For instance, replacing soybean meal by BSFLM in diet increased the abundance of healthpromoting Lactobacillus spp., decreases the abundance of pathogenic Streptococcus spp. and upregulated the expression of anti-inflammatory cytokines in finisher pigs (Yu et al., 2019). Our data provide the first insight into the potential of BSFLM as a nutrient-rich feed ingredient to support maximal lean gain towards attending market 
A
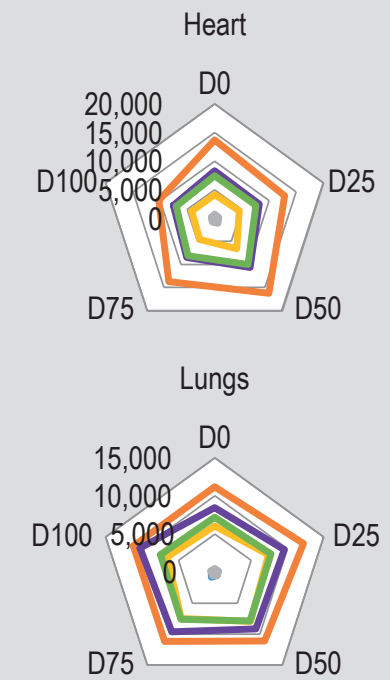

Kidney
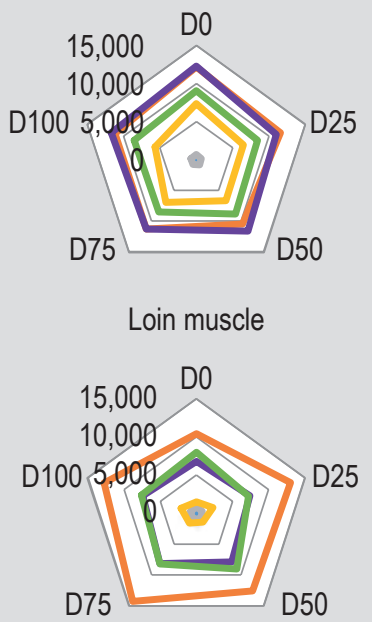

Liver

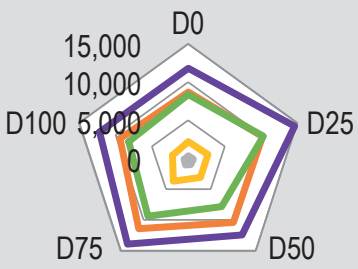

Spleen

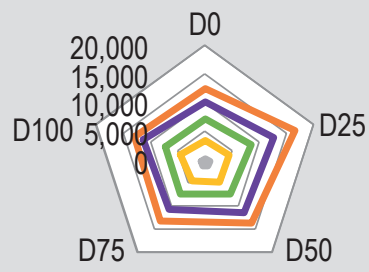

B
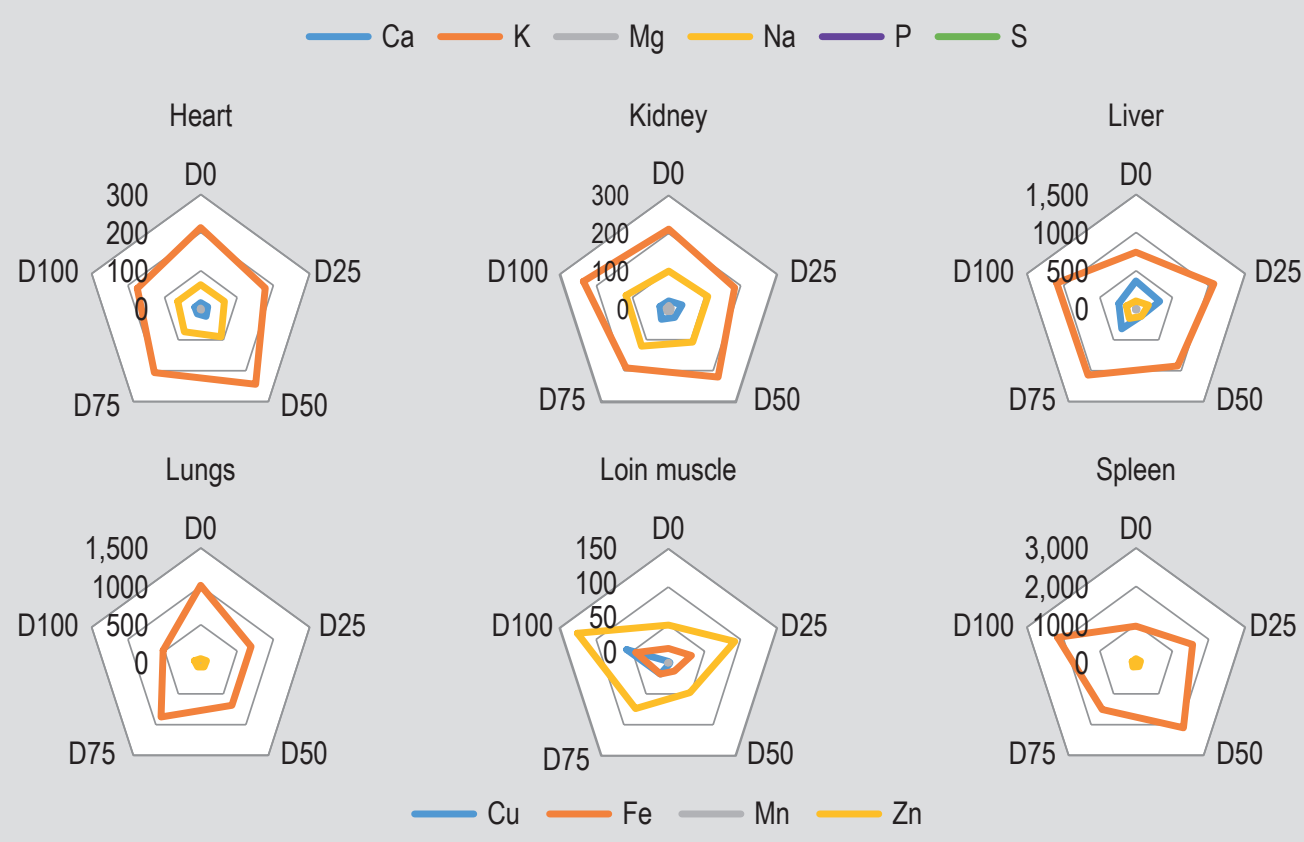

Figure 5. Composition (mg/kg) of (A) macro-minerals and (B) micro-minerals in muscle and organ tissues of slaughtered pigs fed black soldier fly larval meal-based diets and a control diet. DO $=0 \%$ (control), D25 $=25 \%, D 50=50 \%, D 75=75 \%, D 100=100 \%$ levels of replacement of fishmeal with black soldier fly larval meal. $\mathrm{Ca}=$ calcium, $\mathrm{K}=$ potassium, $\mathrm{Mg}=$ magnesium, $\mathrm{Na}=$ sodium, $\mathrm{P}=$ phosphorus, $\mathrm{S}=$ sulphur, $\mathrm{Cu}=$ copper, $\mathrm{Fe}=$ iron, $\mathrm{Mn}=$ manganese, $\mathrm{Zn}=$ zinc. Values presented are results of single analyses. Loin muscle $=$ longissimus dorsi.

weight in finisher pigs. In the present study, BSFLM in feed resulted in better performance of finisher pigs than when fed with conventional feed based on FM. Full-fat BSFLM is rich in $\mathrm{CP}$, amino acids and has a high fat content and thus provides a better source of protein and net energy required for a better growth performance in growing-finishing pigs (Crosbie et al., 2020; Fang et al., 2019; Nekrasov et al., 2018; Yu et al., 2019).

The improved growth performance of finisher pigs in the present study is a clear demonstration of feed tolerance in pigs, a balanced nutrient content and high digestibility of the insect-based diets, which led to optimal feed efficiency. In the literature, studies under other feed regimes showed that pig growth highly depends on the nutrient content of their diet. A protein-rich diet with a balanced amino acid profile leads to high performance (Kim et al., 2005; Nam et al., 1995). Feed intake and quality play essential roles in animal growth performance (Patience et al., 2015). The improved growth performance of pigs with increasing levels of dietary replacement of FM with BSFLM in the present study can be attributed to increased palatability of the diets which resulted in sufficient consumption of digestible nutrients, particularly protein, which support rapid growth. 
This conclusion is supported by the increased ADG, FBW and low FCR for BSFLM-based diets that we recorded.

Pig market weights vary considerably depending on the region, consumer preference or the processing method of the pig when slaughtered. For instance, in Kenya, the recommended pig market weight ranges between 90 and $100 \mathrm{~kg}$ live body weights according to Farmer's Choice Ltd. (Nairobi, Kenya), the main pig market provider in the country. In the present study, the average fasted live body weight of pigs at slaughter ranged between 98 and $121 \mathrm{~kg}$. The weight range in our study falls within the recommended ranges for most other countries (Kim et al., 2005). It is worth noting that pigs fed diets with FM fully replaced by BSFLM had the highest fasted live body weight of 121 $\mathrm{kg}$ while pigs fed the control diet without BSFLM had the lowest live fasted body weight of $98 \mathrm{~kg}$ at slaughter. This corresponds to the higher ADG recorded for pigs at 100\% BSFLM and demonstrates that the replacement of FM with BSFLM in pig feed contributes to faster weight gain, which implies that pigs attain the market weight faster compared to pigs raised on control diets. This is also supported by the low feed conversion ratio values recorded for BSFLMbased diets in this study.

In Kenya, Farmer's Choice recommends and accepts pigs with market sizes ranging from 40 to $120 \mathrm{~kg}$ cold carcass weight. Carcasses within this range are either consumed locally, processed into other pork products or exported whole to other countries. In the present study, the overall carcass weight of pigs ranged between 76 and $94 \mathrm{~kg}$, which is well within the recommended range for pork in Kenya. In our study, pigs fed BSFLM-based diets produced heavier carcasses than those fed the control FM-based diet. Carcasses from all dietary groups had similarly well-formed loin eye, which is one of the quality control features for commercial pork. Therefore, BSFLM is a suitable alternative to FM in commercial pig feed formulation for the Kenyan and international markets.

Daily fat intake is essential for humans because fat provides energy, enhances food palatability and absorption of vitamins (Seong et al., 2014). The fat content of pork tissues in our study was generally higher than values reported in the literature, which could be due to differences in the feeding regime, breed, body weight at slaughter, or processing method of the meat samples (Seong et al., 2014; Valaitiene et al., 2017). The full-fat BSFLM used in our study might have contributed to the crude fat content of the pork tissues. For example, the overall result of fat content shows that pork tissues from pigs fed diets with 50-100\% replacement of FM with BSFLM had higher crude fat levels than those from pigs fed diets with 0-25\% replacement of FM with BSFLM. Moreover, the high fat content in the LM is consistent with the significantly higher value of the subcutaneous fat of the loin cuts recorded for pigs fed D100.
Although the pigs in the control group had a significantly higher fat free index than in the D100 group, the fat free index values were generally above $50 \%$ across all dietary groups, which is an indication of the suitability of BSFLM for finisher pig growth and carcass quality. However, it would be necessary to evaluate this parameter under restricted feeding regimes, because unlimited access to feed and high body weight as in this study might have contributed to an increased fat deposition, consequently impacting the fat free index in pigs in the D100 group (Kim et al., 2005).

The content and distribution of fat in various primal cuts are important characteristics of meat for various market segments (Dunshea and Souza, 2003). In the present study, ham, loin and belly of pigs fed D100 had significantly more fat than in pigs fed the control diet (D0), which can be due to the high fat level of BSF (Wang and Shelomi, 2017). Furthermore, the subcutaneous adipose tissue is the major site of fat deposition in pigs and fat deposition could result from consuming high-carbohydrate diets or pre-formed fats in diets (Dunshea and Souza, 2003). Live body weight is another factor that affects fat deposition in farmed animals (Dunshea and Souza, 2003). In the present study, pigs fed D100 had higher fat content in primal cuts and were heavier than pigs fed D0, which is in line with the studies described by Dunshea and Souza (2003).

In the present study, $\mathrm{K}$ and $\mathrm{P}$ were the most predominant macro-minerals in pork tissues, whose role in human nutrition has been documented (Gupta and Gupta, 2014; $\mathrm{He}$ and MacGregor, 2008). Micro-minerals, which are essential for proper cell functioning were also abundant in pork tissues. The high concentration of minerals in pork tissues in the present study indicates that BSFLM can be considered as a valuable component in pig feed formulation with no adverse effects on nutritional quality of the meat.

In pig production, feed represents an important input. The efficiency with which pigs utilise dietary nutrients for growth, maintenance, lean gain and lipid accretion is crucial and has economic implications for individual and industrial production (Patience et al., 2015). Feed conversion ratio is an important measure of feed efficiency in animal production. A low FCR implies that less feed is required to produce a unit of pork weight, thereby leading to less feed required in a production system. This impacts profitability, feed demand and the competitive position of a feed ingredient against other feed sources (Patience $e t$ al., 2015). Our data show a significant reduction in FCR at higher levels of replacement of FM with BSFLM (with CP values of 15.3, 14.8 and $16.3 \%$ at D50, D75 and D100 respectively), implying that BSFLM-based feed can reduce feed cost in terms of quantity demanded in a finisher pig production. This reduction in FCR positively correlated with body weight gain in the pigs, thus further increasing 
the value of BSFLM in feed. Furthermore, BSFLM is rich in protein, essential amino acids and micronutrients, with a crude protein content well above 30\% (Chia et al., 2020), which contributes to a healthy pig growth and high carcass traits. The protein from BSFLM is of high nutritional quality, with high concentrations of limiting amino acids including lysine and methionine in growing-finishing pig feed (Wang et al., 2018).

\section{Conclusions}

Our study demonstrates that BSFLM is a suitable alternative to FM in feed of finisher pigs, and uniquely combines growth performance, carcass traits and nutritional quality of pigs fed BSFLM-based feeds. Replacement of FM with BSFLM at $50-100 \%$ in pig feeds demonstrated a significant increase in feed conversion, growth (body weight gain) and carcass traits of finisher pigs. Our results, therefore, do not only provide important information for novel insect-based feeds for pig production industries but also provide information on meat nutritional quality for human consumption. Thus, this study holds important opportunities for addressing the increasing scarcity of protein-rich feeds, which is an impediment in pig value chains.

\section{Acknowledgements}

The authors gratefully acknowledge Mr. Ogetonto Wycliffe, Rachami Isaiah E.; Nyamu Faith; Ondiaka Shem, Wambua Joshua and the Non-ruminant Research Institute staff for their technical support in the laboratory and for providing dried black soldier fly larval meal produced at icipe. Also, we are grateful to the Director and all the staff of KALRO for allowing us to access their field station and facilities throughout the experimental period.

\section{Funding}

This work was financially supported by the Netherlands Organization for Scientific Research, WOTRO Science for Global Development (NWO-WOTRO) (ILIPA - W 08.250.202) and the Canadian International Development Research Centre (IDRC) and the Australian Centre for International Agricultural Research (ACIAR) (INSFEED - Phase 2: Cultivate Grant No: 108866-001) and the Rockefeller Foundation (SiPFeed - 2018 FOD 009) through the International Centre of Insect Physiology and Ecology (ICIPE). We also gratefully acknowledge the ICIPE core funding provided by United Kingdom's Foreign, Commonwealth \& Development Office (FCDO); the Swedish International Development Cooperation Agency (Sida); the Swiss Agency for Development and Cooperation (SDC); the Federal Democratic Republic of Ethiopia; and the Government of the Republic of Kenya. The funders had no role in study design, data collection and analysis, decision to publish, or preparation of the manuscript. Therefore, the views expressed herein do not necessarily reflect the official opinion of the donors.

\section{Conflict of interest}

The authors declare no conflict of interest.

\section{Supplementary material}

Supplementary material can be found online at https://doi. org/10.3920/jiff2020.0072

Table S1. Proportion of muscle and bone in primal cuts of half carcasses in pigs fed diets with different levels of black soldier fly larval meal.

Figure S1. Mean $( \pm \mathrm{SE}) 10^{\text {th }}$ rib back fat depth in carcasses of finisher pigs fed BSFLM-based diets and a control diet.

Figure S2. Composition of fat and skin in primal cuts of half carcasses of finisher pigs fed BSFLM-based diets and a control diet.

\section{References}

AOAC, 1990. Official Methods of Analysis of the Association of Analytical Chemists, Arlington, VA, USA.

AOAC, 1995. Official Method 994.12, amino acids in feeds, alternatives I, and III, AOAC - Association of Analytical Chemists, Arlington, VA, USA.

Ardjosoediro, I. and Neven, D., 2008. The Kenya capture fisheries value chain: an AMAP-FSKG value chain finance case study. United States Agency for International Development (USAID), Washington DC, USA. Available at: https://pdf.usaid.gov/pdf_docs/PNADN416.pdf.

Barragan-Fonseca, K.B., Dicke, M. and Van Loon, J.J.A., 2017. Nutritional value of the black soldier fly (Hermetia illucens L.) and its suitability as animal feed - a review. Journal of Insects as Food and Feed 3: 105-120. https://doi.org/10.3920/jiff2016.0055

Belghit, I., Liland, N.S., Gjesdal, P., Biancarosa, I., Menchetti, E., Li, Y.X., Waagbo, R., Krogdahl, A. and Lock, E.J., 2019. Black soldier fly larvae meal can replace fish meal in diets of sea-water phase Atlantic salmon (Salmo salar). Aquaculture 503: 609-619. https:// doi.org/10.1016/j.aquaculture.2018.12.032

Biasato, I., Renna, M., Gai, F., Dabbou, S., Meneguz, M., Perona, G., Martinez, S., Lajusticia, A.C.B., Bergagna, S., Sardi, L., Capucchio, M.T., Bressan, E., Dama, A., Schiavone, A. and Gasco, L., 2019. Partially defatted black soldier fly larva meal inclusion in piglet diets: effects on the growth performance, nutrient digestibility, blood profile, gut morphology and histological features. Journal of Animal Science and Biotechnology 10: 12. https://doi.org/10.1186/ s40104-019-0325-x

Bruinsma, J., 2003. World agriculture: towards 2015/2030 - an FAO perspective. FAO, London, UK. Available at: http://www.fao.org/3/ay4252e.pdf. 
Burson, D., 2006. Procedures for estimating pork carcass composition. U.S. Pork Center of Excellence, Des Moines, IA, USA, 4 pp. Available at: http://porkgateway.org/wp-content/uploads/2015/07/ procedures-for-estimating-pork-carcass-composition1.pdf.

Carter, N.A., Dewey, C.E., Lukuyu, B., Grace, D. and De Lange, C.F. 2015. Nutrient composition and seasonal availability of local feedstuffs for pigs in western Kenya. Canadian Journal of Animal Science 95: 397-406. https://doi.org/10.4141/CJAS-2015-003

Chia, S.Y., Tanga, C.M., Osuga, I.M., Alaru, A.O., Mwangi, D.M., Githinji, M., Subramanian, S., Fiaboe, K.K.M., Ekesi, S., Van Loon, J.J.A. and Dicke, M., 2019. Effect of dietary replacement of fishmeal by insect meal on growth performance, blood profiles and economics of growing pigs in Kenya. Animals 9: 705. https://doi. org/10.3390/ani9100705

Chia, S.Y., Tanga, C.M., Osuga, I.M., Cheseto, X., Ekesi, S., Dicke, M., and Van Loon, J. J.A., 2020. Nutritional composition of black soldier fly larvae feeding on agro-industrial by-products. Entomologia Experimentalis et Applicata 168: 472-481. https://doi.org/10.1111/ eea. 12940

Chia, S.Y., Tanga, C.M., Osuga, I.M., Mohamed, S.A., Khamis, F.M., Salifu, D., Sevgan, S., Fiaboe, K.K.M., Niassy, S., Van Loon, J.J.A., Dicke, M. and Ekesi, S., 2018. Effects of waste stream combinations from brewing industry on performance of black soldier fly, Hermetia illucens (Diptera: Stratiomyidae). Peer J 6: e5885. https://doi. org/10.7717/peerj.5885

Cho, J.H. and Kim, I.H., 2011. Fish meal - nutritive value. Journal of Animal Physiology and Animal Nutrition 95: 685-692. https://doi. org/10.1111/j.1439-0396.2010.01109.x

Crosbie, M., Zhu, C., Shoveller, A.K., and Huber, L.A., 2020. Standardized ileal digestible amino acids and net energy contents in full fat and defatted black soldier fly larvae meals (Hermetia illucens) fed to growing pigs. Translational Animal Science 4: txaa104. https:// doi.org/10.1093/tas/txaa104

Dos Santos, É.J., Baika, L.M., Herrmann, A.B., Kulik, S., Sato, C.S., dos Santos, A.B. and Curtius, A.J., 2012. Fast assessment of mineral constituents in grass by inductively coupled plasma optical emission spectrometry. Brazilian Archives of Biology and Technology 55: 457-464. https://doi.org/10.1590/S1516-89132012000300017

Dunshea, F.R. and Souza, D.N.D., 2003. A review - fat deposition and metabolism in the pig. In: Paterson, J. (ed.) Manipulating pig production IX. Australasian Pig Science Association, Werribee, Australia, pp. 127-150.

Fang, L.H., Jin, Y.H., Do, S.H., Hong, J.S., Kim, B.O., Han, T.H. and Kim, Y.Y., 2019. Effects of dietary energy and crude protein levels on growth performance, blood profiles, and carcass traits in growingfinishing pigs. Journal of Animal Science and Technology 61: 204. https://doi.org/10.5187/jast.2019.61.4.204

Fayemi, P.O., Muchenje, V., Yetim, H. and Ahhmed, A., 2018. Targeting the pains of food insecurity and malnutrition among internally displaced persons with nutrient synergy and analgesics in organ meat. Food Research International 104: 48-58. https://doi. org/10.1016/j.foodres.2016.11.038

Fiaboe, K. and Nakimbugwe, D., 2017. INSFEED - integrating insects in poultry and fish feed in Kenya and Uganda. Final technical report. IDRC project number: 107839. Available at: http://hdl.handle. net/10625/56858.
Githigia, S.M., Okuthe, S. and Diop, B., 2012. Pig sector Kenya. FAO Animal Production and Health Livestock Country Reviews. No. 3. FAO, Rome, Italy. Available at: http://www.fao.org/3/a-i2566e.pdf.

Gupta, U.C. and Gupta, S.C., 2014. Sources and deficiency diseases of mineral nutrients in human health and nutrition: a review. Pedosphere 24: 13-38. https://doi.org/10.1016/s10020160(13)60077-6

He, F.J. and MacGregor, G.A., 2008. Beneficial effects of potassium on human health. Physiologia Plantarum 133: 725-735. https://doi. org/10.1111/j.1399-3054.2007.01033.x

Kagira, J.M., Maingi, N., Kanyari, P.W.N., Githigia, S.M. and Gachohi, J.M., 2010. Characteristics of pig trade in low income settings in Busia District, Kenya. Tanzania Veterinary Journal 27: 27-35. https:// doi.org/10.4314/tvj.v27i1.62762

Kim, Y.S., Kim, S.W., Weaver, M.A. and Lee, C.Y., 2005. Increasing the pig market weight: world trends, expected consequences and practical considerations. Asian-Australasian Journal of Animal Sciences 18: 590-600. https://doi.org/10.5713/ajas.2005.590

Kolding, J., Medard, M., Mkumbo, O. and Van Zwieten, P.A.M., 2014. Status, trends and management of the lake Victoria fisheries, Inland fisheries evolution and management. case studies from four continents. FAO Fisheries and Aquaculture Technical Paper No. 579. FAO, Rome, Italy, pp. 49-62. Available at: http://www.fao. org/3/a-i3572e.pdf.

Llames, C.R. and Fontaine, J., 1994. Determination of amino-acids in feeds - collaborative study. Journal of AOAC International 77: 1362-1402. https://doi.org/10.1093/jaoac/77.6.1362

Lowell, J.E., Bohrer, B.M., Wilson, K.B., Overholt, M.F., Harsh, B.N., Stein, H.H., Dilger, A.C. and Boler, D.D., 2018. Growth performance, carcass quality, fresh belly characteristics, and commercial bacon slicing yields of growing-finishing pigs fed a subtherapeutic dose of an antibiotic, a natural antimicrobial, or not fed an antibiotic or antimicrobial. Meat Science 136: 93-103. https://doi.org/10.1016/j. meatsci.2017.10.011

Makkar, H.P.S., Tran, G., Henze, V. and Ankers, P., 2014. Stateof-the-art on use of insects as animal feed. Animal Feed Science and Technology 197: 1-33. https://doi.org/10.1016/j. anifeedsci.2014.07.008

Mbuthia, J.M., Rewe, T.O. and Kahi, A.K., 2015. Evaluation of pig production practices, constraints and opportunities for improvement in smallholder production systems in Kenya. Tropical Animal Health and Production 47: 369-376. https://doi.org/10.1007/s11250-0140730-2

Meneguz, M., Schiavone, A., Gai, F., Dama, A., Lussiana, C., Renna, M. and Gasco, L., 2018. Effect of rearing substrate on growth performance, waste reduction efficiency and chemical composition of black soldier fly (Hermetia illucens) larvae. Journal of the Science of Food and Agriculture 98: 5776-5784. https://doi.org/10.1002/ jsfa.9127

Mohammed, E., Mohammed, T. and Mohammed, A., 2017. Optimization of an acid digestion procedure for the determination of $\mathrm{Hg}, \mathrm{As}, \mathrm{Sb}, \mathrm{Pb}$ and Cd in fish muscle tissue. Methodsx 4: 513-523. https://doi.org/10.1016/j.mex.2017.11.006 
Mutua, F.M., Arimi, S.M., Ogara, W.O., Dewey, C.E. and Schelling, E., 2010. Farmer perceptions on indigenous pig farming in Kakamega district, Western Kenya. Nordic Journal of African Studies 19: 4357. https://www.njas.fi/njas/article/view/213/201

Nalwanga, R., Liti, D.M., Waidbacher, H., Munguti, J. and Zollitsch, W.J., 2009. Monitoring the nutritional value of feed components for aquaculture along the supply chain - an East African case study. Livestock Research for Rural Development 21: Article \#148. Available at: http://www.lrrd.org/lrrd21/9/nalw21148.htm.

Nam, D.S., Aherne, F.X. and Darroch, C.S., 1995. Growth performance of pigs given a choice of natural ingredient diets containing different levels of protein and amino acid(s). Animal Feed Science and Technology 56: 265-276. https://doi.org/10.1016/03778401(95)00836-5

National Research Council, 1979. Nutrient requirements of swine: eighth revised edition. NRC-National Research Council, Washington DC, USA. Available at: https://doi.org/10.17226/19882.

Nekrasov, R., Zelenchenkova, A., Chabaev, M., Ivanov, G., Antonov, A., and Pastukhova, N. 2018. PSIII-37 dried black soldier fly larvae as a dietary supplement to the diet of growing pigs. Journal of Animal Science 96: 314-314. https://doi.org/10.1093/jas/sky404.691

Newton, G.L., Booram, C.V., Barker, R.W. and Hale, O.M., 1977. Dried Hermetia illucens larvae meal as a supplement for swine. Journal of Animal Science 44: 395-400. https://doi.org/10.2527/ jas1977.443395x

Njoku, C.P., Adeyemi, O.A., Sogunle, O.M. and Aina, A.B.J., 2015. Growth performance, carcass yield and organ weight of growing pigs fed different levels of feed. Slovak Journal of Animal Science 48: 16-22. https://sjas.ojs.sk/sjas/article/download/180/168/

Núñez-Sánchez, N., Martínez Marín, A.L., Hernández, M.P., Carrion, D., Castro, G.G. and Pérez Alba, L.M., 2012. Faecal near infrared spectroscopy (NIRS) as a tool to asses rabbit's feed digestibility. Livestock Science 150: 386-390. https://doi.org/10.1016/j. livsci.2012.07.030

Onsongo, V.O., Osuga, I.M., Gachuiri, C.K., Wachira, A.M., Miano, D.M., Tanga, C.M., Ekesi, S., Nakimbugwe, D. and Fiaboe, K.K.M., 2018. Insects for income generation through animal feed: effect of dietary replacement of soybean and fish meal with black soldier fly meal on broiler growth and economic performance. Journal of Economic Entomology 111: 1966-1973. https://doi.org/10.1093/ jee/toy118

Ouma, E., Dione, M., Lule, P., Roesel, K. and Pezo, D., 2014. Characterization of smallholder pig production systems in Uganda: constraints and opportunities for engaging with market systems. Livestock Research for Rural Development 26: 56. http://www.lrrd. org/lrrd26/3/ouma26056.htm

Patience, J.F., Rossoni-Serao, M.C. and Gutierrez, N.A., 2015. A review of feed efficiency in swine: biology and application. Journal of Animal Science and Biotechnology 6: 33. https://doi.org/10.1186/ s40104-015-0031-2

Rosales, A., Galicia, L., Oviedo, E., Islas, C. and Palacios-Rojas, N., 2011. Near-infrared reflectance spectroscopy (nirs) for protein, tryptophan, and lysine evaluation in quality protein maize (QPM) breeding programs. Journal of Agricultural and Food Chemistry 59: 10781-10786. https://doi.org/10.1021/jf201468x
Seong, P.N., Park, K.M., Cho, S.H., Kang, S.M., Kang, G.H., Park, B.Y., Moon, S.S. and Ba, H.V., 2014. Characterization of edible pork byproducts by means of yield and nutritional composition. Korean Journal for Food Science of Animal Resources 34: 297-306. https:// doi.org/10.5851/kosfa.2014.34.3.297

Sheppard, D.C., Newton, G.L., Thompson, S.A. and Savage, S., 1994. A value-added manure management-system using the black soldier fly. Bioresource Technology 50: 275-279. https://doi.org/10.1016/09608524(94)90102-3

Sheridan, J.J., Allen, P., Ziegler, J.H., Marinkov, M., Suvakov, M.D. and Heinz, G., 1991. Guidelines for slaughtering, meat cutting and further processing. FAO, Rome, Italy. Available at: http://www.fao. org/3/T0279E/T0279E00.htm.

Spranghers, T., Michiels, J., Vrancx, J., Ovyn, A., Eeckhout, M., De Clercq, P. and De Smet, S., 2018. Gut antimicrobial effects and nutritional value of black soldier fly (Herrnetia illucens L.) prepupae for weaned piglets. Animal Feed Science and Technology 235: 33-42. https://doi.org/10.1016/j.anifeedsci.2017.08.012

Sreenivasulu, V., Kumar, N.S., Dharmendra, V., Asif, M., Balaram, V., Zhengxu, H. and Zhen, Z., 2017. Determination of boron, phosphorus, and molybdenum content in biosludge samples by microwave plasma atomic emission spectrometry (MP-AES). Applied Sciences 7: 264. https://doi.org/10.3390/app7030264

Valaitiene, V., Stanyte, G., Klementaviciute, J. and Jankauskas, A., 2017. Nutritional value of and element content in meat from various pig breeds. Animal Science Papers and Reports 35: 419-428. Available at: https://tinyurl.com/y5kb3qad.

Van Krimpen, M.M. and Hendriks, W.H., 2019. Novel protein sources in animal nutrition: considerations and examples. In: Hendriks, W.H. Verstegen, M.W.A. and Babinszky, L. (eds) Poultry and pig nutrition. Wageningen Academic Publishers, Wageningen, the Netherlands, pp. 279-305. https://doi.org/10.3920/978-90-8686-884-1_13

Wang, Y.-S. and Shelomi, M., 2017. Review of black soldier fly (Hermetia illucens) as animal feed and human food. Foods 6: 91. https://doi.org/10.3390/foods6100091

Wang, Y., Zhou, J., Wang, G., Cai, S., Zeng, X. and Qiao, S., 2018. Advances in low-protein diets for swine. Journal of Animal Science and Biotechnology 9: 60. https://doi.org/10.1186/s40104-018-0276-7 Xiao, X.P., Jin, P., Zheng, L.Y., Cai, M.M., Yu, Z.N., Yu, J. and Zhang, J.B., 2018. Effects of black soldier fly (Hermetia illucens) larvae meal protein as a fishmeal replacement on the growth and immune index of yellow catfish (Pelteobagrus fulvidraco). Aquaculture Research 49: 1569-1577. https://doi.org/10.1111/are.13611

Yu, M., Li, Z.M., Chen, W.D., Rong, T., Wang, G. and Ma, X.Y., 2019. Hermetia illucens larvae as a potential dietary protein source altered the microbiota and modulated mucosal immune status in the colon of finishing pigs. Journal of Animal Science and Biotechnology 10: 50. https://doi.org/10.1186/s40104-019-0358-1

Zarantoniello, M., Bruni, L., Randazzo, B., Vargas, A., Gioacchini, G., Truzzi, C., Annibaldi, A., Riolo, P., Parisi, G., Cardinaletti, G., Tulli, F. and Olivotto, I., 2018. Partial dietary inclusion of Hermetia illucens (black soldier fly) full-fat prepupae in zebrafish feed: biometric, histological, biochemical, and molecular implications. Zebrafish 15: 519-532. https://doi.org/10.1089/zeb.2018.1596 
